Available online at GSC Online Press Directory

GSC Biological and Pharmaceutical Sciences

e-ISSN: 2581-3250, CODEN (USA): GBPSC2

Journal homepage: https://www.gsconlinepress.com/journals/gscbps

(RESEARCH ARTICLE)

\title{
Effects (in vivo) of the nutritional potential of snail Limicolaria flammea (Müller) meat on wistar rats
}

\author{
Envin Bogui Jacques Anicet 1, Ekissi Elvis Serge Gbocho ${ }^{2,}{ }^{*}$, Sea Tehi Bernard ${ }^{1}$, Rougbo N'djoman Paterne \\ and Kouamé Lucien Patrice 2 \\ ${ }^{1}$ Department of Food Science and Technology, Laboratory of Biocatalysis and Bioprocessing, University Nangui \\ Abrogoua. \\ 2 Department of Biochemistry, University Felix Houphouët-Boigny.
}

Publication history: Received on 20 April 2020; revised on 04 May 2020; accepted on 06 May 2020

Article DOI: https://doi.org/10.30574/gscbps.2020.11.2.0108

\begin{abstract}
Development of new animal protein sources contributes to the fight against protein deficiencies in diets of populations in sub-Saharan Africa. This study was investigated to assess the impact of snail flesh (Limicolaria flammea) diet on biochemical and zootechnical parameters of young wistar rats. Thus, three diets (RTC, ESC and RPP) were made and submitted to these rats for 15 days. The biochemical analysis of snail flesh (Limicolaria flammea) powder having served as a protein source $(46.65 \pm 0.05 \%)$ is also rich in ash $(6.23 \pm 0.01 \%)$, calcium $(1654.54 \pm 0.06 \mathrm{mg} / 100 \mathrm{~g})$, potassium $(1324.54 \pm 4.18 \mathrm{mg} / 100 \mathrm{~g})$ and sodium $(668.69 \pm 1.13 \mathrm{mg} / 100 \mathrm{~g})$. The results showed that the constituted diets had a significant impact on the rats weight compared to the control diet (RTC) with an average daily variation of $+2.08 \mathrm{~g} / \mathrm{J}$ (RTC); $1.68 \mathrm{~g} / \mathrm{J}(\mathrm{ESC})$ and $-0.69 \mathrm{~g} / \mathrm{J}$ (RPP) with respective final weights at the end of the experiment of $68.12 \pm 1 \mathrm{~g}$; $68.12 \pm 1 \mathrm{~g}$ and $45.3 \pm 1 \mathrm{~g}$. Furthermore, the ESC diet had no negative impact on the weight of vital organs. The organs weights such as the heart $(0.52 \pm 0.04 \mathrm{~g})$, liver $(3.19 \pm 0.96 \mathrm{~g})$, spleen $(0.28 \pm 0.03 \mathrm{~g})$, kidneys $(0.80 \pm 0.04 \mathrm{~g})$ and abdominal fat $(0.85 \pm 0.08 \mathrm{~g})$ of fed rats on the diet (ESC) showed no significant difference $(\mathrm{p}<0.05)$ with those of rats fed the control $\operatorname{diet}(\mathrm{BTI})$.
\end{abstract}

Keywords: Diets; In vivo; Limicolaria flammea; Wistar rats; Zoo technical; Biochemical parameters.

\section{Introduction}

Snail meat popularly has been described as a high quality food that is rich in protein, iron, contain high levels of magnesium, phosphorous and potassium but low levels of sodium, fat and cholesterol [1, 2, 3]. In West Africa, snail meat has traditionally been a major source of protein in the diet of people living in the forest belt [4,5]. In addition, there are claims that snail meat has medicinal value and can be used to treat ailments including whooping cough, anaemia, asthma, and high blood pressure due to their relatively low cholesterol level but high mineral content [6,7]. The four main species of edible land snails of the moist forest belt of Nigeria are Archachatina marginata (Swainson), Archachatina papyracae (Pfeiffer), Limicolaria flammea (Muller) and Limicolaria aurora (Jay) [8]. They are widely distributed in the moist forest belts of West Africa (Nigeria, the Republic of Benin, Togo, Côte d'Ivoire, Liberia, and Sierra Leone) [8] . Several African snails of the family Achatinidae have attained notoriety as pests [9].

The Limicolaria flammea (Muller) is the smallest breed of common edible land snails. It is also known as garden snails. Limicolaria flammea is a species of tropical air-breathing land snail, a terrestrial pulmonate gastropod mollusk in the family Achatinidea [10]. The snail meat is mainly consumed as delicacy characterized by a high dietetic value and excellent nutritious traits [11]. Research shows that it is rich in protein at the same time being low in lipids [12,13].

\footnotetext{
* Corresponding author: Ekissi Elvis Serge Gbocho
} 
Contribution of so-called minor foods (insects, molluscs, crustaceans) remains to this day an undeniable alternative to food security. Several awareness-raising campaigns to address new food security constraints in countries in transition or changing dietary habits are being promoted [14]. The subscription to this approach by populations made vulnerable by the low availability of traditional protein sources will contribute to changing the permanent context linked to food insecurity, which is at the root of malnutrition [15]. To this end, snail meat is highly valued by populations because of its considerable nutritional and protein content [16]. Snail meat contains more than $40 \%$ protein and high levels of minerals, mainly calcium and phosphorus [17]. Snail consumption remains high in West Africa, particularly in Côte d'Ivoire where annual consumption is around 1700 tonnes [18]. However, the orientation towards this objective alternative of food security is hampered by socio-cultural considerations that favour discrimination by certain populations in the consumption of certain snail species [19]. These prejudices emanate from eating habits that often differ from one individual to another and thus ensure a depreciation of certain species, namely the Limicolaria flammea snail, in favour of other snail species, such as Archachatina marginata or Achatina achatina [20]. The present work therefore, investigated nutritional potential of snail meat (Limicolaria flammea) diet and the influence on the young growing rats.

\section{Material and methods}

The biological material consists of Limicolaria flammea snails and young rats of the wistar Ratus norvegus strain aged 45 to 55 days. Snails were collected in Agboville (South-east of Côte d'Ivoire). The availability of experimental rats was ensured by the pharmacology and nutrition laboratory of the UFR of pharmaceutical and biological sciences at Félix Houphouët-Boigny University (Abidjan, Côte d'Ivoire).

\subsection{Animal material}

The Wistar rats (Rattus norvegicus) used in these experiments were supplied by the animal facility of Higher Normal School (ENS) located within the Felix Houphouët -Boigny University (Abidjan, Côte d'Ivoire).

\subsection{Production of snail powder}

The snails (Limicolaria flammea) collected were left on an empty stomach for two days in order to release their excrement. A batch of 500 snails used, were removed from their shells and their flesh separated from the other organs by a stainless knife. , the snail meat was baked in an oven $\left(80^{\circ} \mathrm{C}\right)$, crushed and then sieved through different sieves $(1000 ; 750 ; 500 ; 500 ; 250 \mu \mathrm{m})$ to obtain the fine snail (Limicolaria flammea) powder.

\subsection{Food inputs and diet formulation}

Three diets were formulated to feed the young rats. A diet based on herring fish (Clupea harengus) powder, a diet of snail (Limicolaria flammea) powder and a diet deprived of proteins (animal and vegetable). White corn starch (Merck) is the main source of carbohydrates for inputs. Palm oil (Aya) provides essential fatty acids. Herring fish (Clupea harengus) is the source of control protein. Mixture of vitamins and minerals used, is a veterinary powder called "vitaflash".

\subsection{Diets Formulation}

A mass of $240 \mathrm{~g}$ of Limicolaria flammea snail powder (ESC) and Clupea harengus herring fish (RTC) was collected separately. To each quantity, 975g of starch (Merck), $120 \mathrm{~g}$ of vegetable oil "Aya", $15 \mathrm{~g}$ of vitamin and mineral supplement "Vitaflash" were added and the whole kneaded homogeneously and cooked for 15 minutes with $1250 \mathrm{ml}$ of 'distilled water. The private protein diet (RPP) was performed under the same conditions, but free of protein (Table 1)

Table 1 Diet formulation and food inputs

\begin{tabular}{lllll}
\hline Food inputs & MS (\%) & RTC & ESC & RPP \\
\hline Protein & 16 & 240 & 240 & 0 \\
Merck Starch & 65 & 975 & 975 & 1215 \\
Palm oil (Aya) & 8 & 120 & 120 & 120 \\
Vitamin and mineral supplement & 8 & 15 & 15 & 15 \\
Cellulose & 3 & 45 & 45 & 45 \\
Dry matter & 100 & 1500 & 1500 & 1500 \\
Energy value (Kcal/Kg) & & 5940 & 5940 & 5940 \\
\hline
\end{tabular}




\subsection{Biochemical and nutritional composition}

Physicochemical and biochemical characteristics as well as the dry matter content and fibers content were determined by [21] method. Protein content of snail powder was determined by Kjedahls [22] method using 6.25 as the conversion factor. Fat content was determined after 6 hours of Soxhlet hexane extraction [21]. Carbohydrate content was determined by calculation using the term described by [23] . Total carbohydrate was obtained by subtracting the per cent amounts of crude protein, crude fat, moisture, and ash from 100\%: Carbohydrate (\%) $=100 \%-(\%$ Moisture $+\%$ Ash $+\%$ Fat $+\%$ Protein). The energy value of the snail sample was obtained by multiplying the per cent composition of protein, fat, and carbohydrate by their corresponding Atwater values of 17, 37, and 17, respectively [24].

\subsection{In vivo nutritional assessment of diets}

A batch of twelve wistar rats (45 to 50 days of age) from Pharmacology and Nutrition Laboratory of Félix HouphouëtBoigny University (Abidjan, Côte d'Ivoire) was used to carry out the experiment. The young rats with weights of 45 and $55 \mathrm{~g}$ were divided into three batches of four rats. Each wistar rat was isolated in a minicage. Lot 1 was subjected to a private protein diet, lot 2 to the herring fish (Clupea harengus) diet and lot 3 to the snail (Limicolaria flammea) powder diet. The experimental phase carried out according to [25] was done in two stages. Stage 1: adaptation or acclimatization phase of young rats lasted 5 days. During this period, the young rats were subjected to commercial-type granules. Stage 2 consisted of feeding each wistar rat $30 \mathrm{~g}$ of food made from the diets produced for 15 days. Each day, the remains of each diet and waste are discarded and weighed. The weight of each wistar rat was assessed every 3 days apart. The faeces and urine of each rat were collected, weighed, dried in the oven $\left(70{ }^{\circ} \mathrm{C}, 24\right.$ hours $)$ and then ground. During this phase, parameters (weight gain, total dry matter ingested, food efficiency ratio, total protein ingested, protein retention, net protein used, apparent digestibility, protein efficiency ratio and biological value) were determined (Table2 ).

Table 2 Mathematical expressions of nutritional parameters

\begin{tabular}{ll}
\hline Nutritional parameters & \multicolumn{1}{c}{ Mathematical expressions } \\
\hline MSI & {$[$ As $-\mathrm{Ar}](\mathrm{g}) \times \mathrm{MS}(\%)$} \\
CEA & GP / MSI \\
PTI & MSI x Dietary proteins (\%) \\
RP & $\mathrm{I}-(\mathrm{Fe}-\mathrm{Fpp})-(\mathrm{U}-\mathrm{Upp})$ \\
PNU & {$[\mathrm{I}-(\mathrm{Fe}-\mathrm{Fpp})-(\mathrm{U}-\mathrm{Upp})] / \mathrm{I}$} \\
Da & {$[\mathrm{I}-\mathrm{F}] / \mathrm{I}$} \\
CEP & $\mathrm{GP} / \mathrm{PTI}$ \\
VB & {$[\mathrm{I}-(\mathrm{Fe}-\mathrm{Fpp})-(\mathrm{U}-\mathrm{Upp})] / \mathrm{I}-(\mathrm{Fe}-\mathrm{Fpp})$} \\
\hline
\end{tabular}

As: Food served, GP : Weight gain, Ar : Feed refused, MS(\%) : Dry matter rate MSI : Dry matter ingested, CEA : Food efficiency ratio, PTI : Total protein ingested RP : Protein retention, PNU : Net protein used, Da : Apparent digestibility; CEP: Protein efficiency ratio, VB: Biological value, I: Amount of dietary protein ingested ; F: Amount of dietary protein excreted in faeces, Fe : Protein excreted by faeces of a subject other than the one fed a protein-free diet, Fpp : Proteins excreted by faeces of a subject fed a protein-free diet, $U$ : Protein excreted in urine of a subject other than the one fed a protein-free diet, Upp: Protein excreted in urine of a subject fed a protein-free diet

\subsection{Weight of rats organs}

At the end of experimental phase (fifteen days), rats in each batch were sacrificed according to method described by [25]. Organs (liver, kidneys, spleen and fat) were collected and weighed. Gross weight of rats organs sampled made it possible to evaluate rats weight of the organs according to the following equation:

$$
\text { Organ weight }(\%)=\frac{\text { Gross organ weight }}{\text { Rats weight }} \times 100
$$

\subsection{Statistical analysis}

The experiment was carried out in triplicate for proximate analysis and fivefold for nutritional evaluation. Data obtained were analyzed by Analysis of Variance (ANOVA) using the software IBM SPSS Statistics version 20.0. Differences between means were tested using the Duncan Multiple Range Test with 5\% level of significance. 


\section{Results and discussion}

\subsection{Biochemical and nutritional parameters}

Biochemical and nutritional parameters of snail powder (Limicolaria flammea), herring fish (Clupea harengus) and corn flour are presented in table 3. Snail powder of Limicolaria flammea had high content in protein (46.65 $\pm 0.05 \%)$, calcium

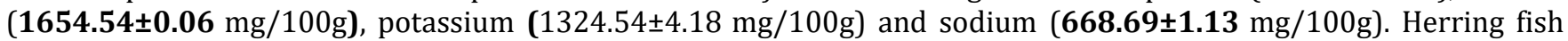
powder had high content in ash $(8.33 \pm 0.16 \%)$, protein $(63.06 \pm 0.6 \%)$, fat $(10.5 \pm 0.6 \%)$. Corn flour had a high humidity $(10.88 \pm 2.3 \%)$, carbohydrate $(70.7 \pm 2.1 \%)$, total sugars $(16.3 \pm 3.4 \%)$ and reducing sugars $(20.2 \pm 1.8 \%)$ contents. Energy value of Herring fish powder (Clupea harengus), snail powder (Limicolaria flammea), maize flour are $397.94 \pm 5.2$ $\mathrm{Kcal} / 100 \mathrm{~g}, 301.18 \pm 5.6 \mathrm{Kcal} / 100 \mathrm{~g}$ and $335.48 \pm 7.8 \mathrm{Kcal} / 100 \mathrm{~g}$ respectively. Most of biochemical and nutritional parameters differ significantly $(\mathrm{p}<0.05)$.

Table 3 Biochemical and nutritional parameters of biological materials

\begin{tabular}{llll}
\hline Parameters (\%) & $\begin{array}{l}\text { Snail powder } \\
\text { flammea) }\end{array}$ & $\begin{array}{l}\text { (Limicolaria } \\
\text { Herring fish powder }\end{array}$ & $\begin{array}{l}\text { Helupea harengus) } \\
\text { Corn flour }\end{array}$ \\
\hline Humidity & $9.44 \pm 0.01^{\mathrm{a}}$ & $9.85 \pm 1.25^{\mathrm{b}}$ & $10.88 \pm 2.3^{\mathrm{c}}$ \\
Ash & $6.23 \pm 0.01^{\mathrm{a}}$ & $8.33 \pm 0.16^{\mathrm{b}}$ & $1.32 \pm 0.06^{\mathrm{c}}$ \\
Fibers & $1.2 \pm 0.25^{\mathrm{a}}$ & $0.87 \pm 0.01^{\mathrm{b}}$ & $0.00^{\mathrm{c}}$ \\
pH & $7.2 \pm 0.36^{\mathrm{a}}$ & $6.3 \pm 1.2^{\mathrm{b}}$ & $6.8 \pm 1.6^{\mathrm{a}}$ \\
Total Carbohydrate & $8.20 \pm 0.01^{\mathrm{a}}$ & $16.38 \pm 3.1^{\mathrm{b}}$ & $70.7 \pm 2.1^{\mathrm{c}}$ \\
Total sugars & $7.8 \pm 0.25^{\mathrm{a}}$ & $6.2 \pm 0.3^{\mathrm{b}}$ & $16.3 \pm 3.4^{\mathrm{c}}$ \\
Reducing sugars & $7.23 \pm 0.04^{\mathrm{a}}$ & $6.6 \pm 1.6^{\mathrm{b}}$ & $20.2 \pm 1.8^{\mathrm{c}}$ \\
Protein & $46.65 \pm 0.05^{\mathrm{a}}$ & $63.06 \pm 0.6^{\mathrm{b}}$ & $8.76 \pm 3.6^{\mathrm{c}}$ \\
Fat & $8.64 \pm 0.64^{\mathrm{a}}$ & $10.5 \pm 0.6^{\mathrm{b}}$ & $1.96 \pm 1.6^{\mathrm{c}}$ \\
Sodium (mg/100g) & $668.69 \pm 1.13^{\mathrm{a}}$ & $10.3 \pm 2.1^{\mathrm{b}}$ & - \\
Potassium (mg/100g) & $1324.54 \pm 4.18^{\mathrm{a}}$ & $8.63 \pm 1.5^{\mathrm{b}}$ & - \\
Calcium (mg/100g) & $1654.54 \pm 0.06^{\mathrm{a}}$ & $3.54 \pm 1.25^{\mathrm{b}}$ & - \\
Energy value (Kcal/100g) & $301.18 \pm 5.6^{\mathrm{a}}$ & $397.94 \pm 5.2^{\mathrm{b}}$ & $335.48 \pm 7.8^{\mathrm{c}}$ \\
\hline
\end{tabular}

\subsection{Nutritional biochemical parameters}

Table 4 Diets nutritional parameters

\begin{tabular}{llll}
\hline Parameters (\%) & \multicolumn{1}{c}{ RTC } & \multicolumn{1}{c}{ ESC } & RPP \\
\hline MSI (g/j) & $7.88 \pm 0.53^{\mathrm{a}}$ & $8.53 \pm 1.05^{\mathrm{a}}$ & $7.88 \pm 0.55^{\mathrm{a}}$ \\
CEA & $0.37 \pm 0.45^{\mathrm{a}}$ & $0.12 \pm 0.03^{\mathrm{b}}$ & $-0.15 \pm 0.05^{\mathrm{c}}$ \\
PTI (g/j) & $1.37 \pm 0.15^{\mathrm{b}}$ & $3.72 \pm 0.45^{\mathrm{a}}$ & nd \\
CEP & $2.81 \pm 0.31^{\mathrm{a}}$ & $2.7 \pm 0.29^{\mathrm{a}}$ & nd \\
DA & $84.12 \pm 1.31^{\mathrm{a}}$ & $88.14 \pm 0.9^{\mathrm{a}}$ & nd \\
DR & $95.54 \pm 0.36^{\mathrm{a}}$ & $93.38 \pm 0.37^{\mathrm{a}}$ & nd \\
VB & $81.92 \pm 1.56^{\mathrm{b}}$ & $93.66 \pm 0.42^{\mathrm{a}}$ & nd \\
RP (g/j) & $4.74 \pm 0.49^{\mathrm{a}}$ & $3.82 \pm 0.19^{\mathrm{a}}$ & nd \\
PNU & $79.32 \pm 0.02^{\mathrm{a}}$ & $80.03 \pm 0.74^{\mathrm{a}}$ & nd
\end{tabular}

nd: not determined; MSI: Dry matter ingested, CEA: Food efficiency ratio; PTI: Total protein ingested; CEP: Protein efficiency ratio; DA: Apparent digestibility; VB: Biological value, GP: Weight gain, RP: Protein retention; PNU : Net protein used 
Nutritional biochemical parameters are presented in Table 4. This experimental study revealed most of nutritional biochemical parameters (MSI, CEP, DA, DR, RP, PNU) don't differ significantly $(\mathrm{p}<0.05)$. However, following ingestion of diets such as snail diet (Limicolaria flammea = ESC) and protein control diet (Clupea harengus), the dietary efficiency coefficient (CEA) and total ingested protein (TIP) differ significantly $(p<0.05)$ in young rats fed respectively with these two diets. On the other hand, the feed efficiency coefficient of young rats fed the protein-free diet is negative, unlike the other parameters analyzed in rats fed the protein control diet (Clupea harengus) and the snail diet (ESC).

\subsection{Effect diets on rats weight}

\subsubsection{Effect diets on rats weight}

The weights of rats varied from one food source to another. The weights of rats fed the RPP diet decreased throughout the experiment (fifteen days) while the weights of rats fed the RTC and ESC diet increased. The weights of rats fed the BTI diet are the highest.

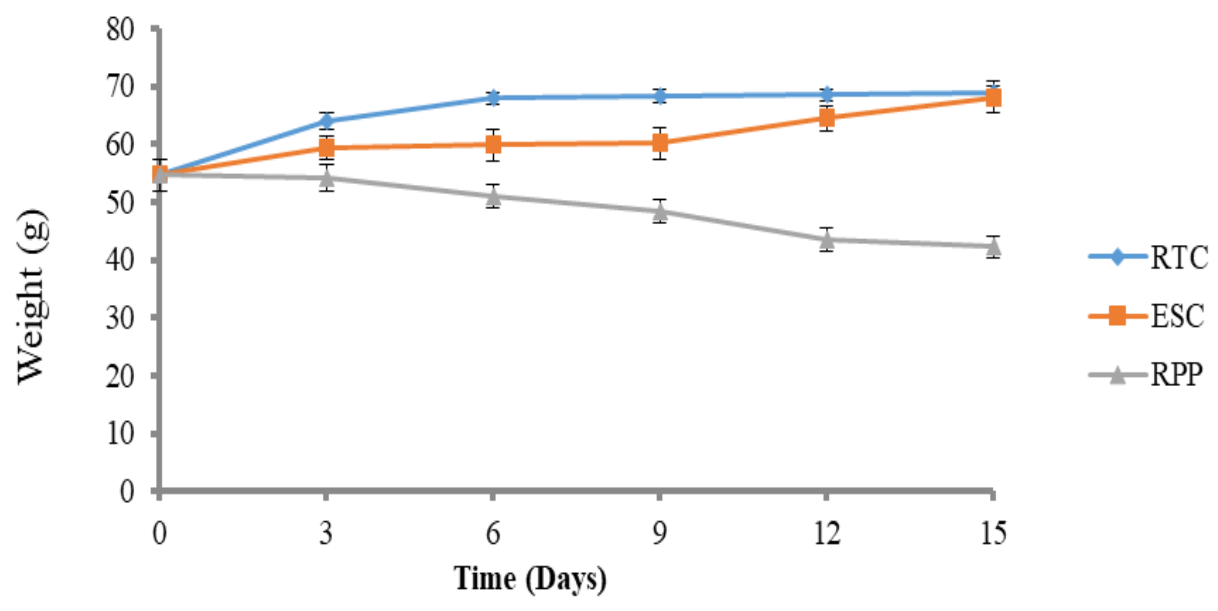

Figure 1 Rats weight on different diets

\subsubsection{Effect diets on rats weight variation}

The different variations in weight of the rats (gain or loss) during the experimental phase are presented in figure 2. The rats fed on the RTC and ESC regimes present variations in positive weight (weight gain) and this gain is even more significant with the RTC regime. Rats fed RPP diets show weight loss.

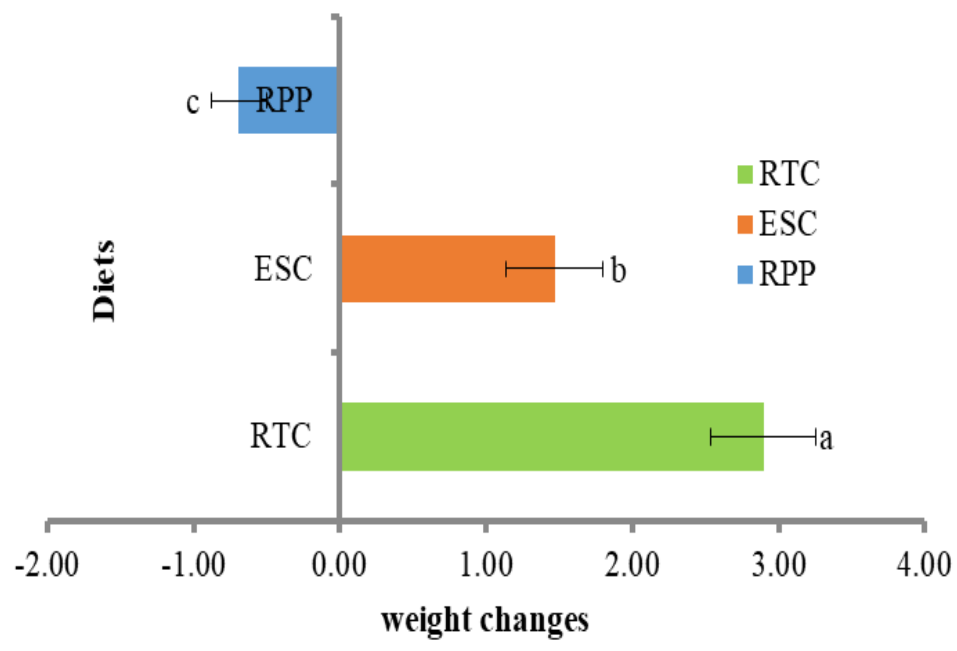

Figure 2 Changes in rats weights (gain or loss) 


\subsubsection{Weight of organs and fat}

The evaluation of organs weight of the rats was carried out at the end of the experimental phase (after rats sacrifice) and generally shows that the heart and fat weight of young rats don't differ significantly whatever their diet. In contrast, the spleen of rats fed the RTC diet is almost twice as heavy as that of rats fed the ESC and RPP diet. The organ weights (liver and kidneys) of rats fed diets of snails (Limicolaria flammea) and herring fish (Clupea harengus), respectively are almost identical (Table 4).

Table 5 Weights (g) of Wistar rats organs

\begin{tabular}{llll}
\hline Organs & ESC & RPP & RTC \\
\hline Heart & $0.52 \pm 0.04 \mathrm{a}$ & $0.51 \pm 0.02 \mathrm{a}$ & $0.51 \pm 0.06 \mathrm{a}$ \\
Liver & $3.19 \pm 0.96 \mathrm{a}$ & $2.17 \pm 0.41 \mathrm{~b}$ & $3.01 \pm 0.32 \mathrm{a}$ \\
Spleen & $0.28 \pm 0.03 \mathrm{a}$ & $0.23 \pm 0.01 \mathrm{a}$ & $0.47 \pm 0.07 \mathrm{~b}$ \\
kidneys & $0.80 \pm 0.04 \mathrm{a}$ & $0.75 \pm 0.10 \mathrm{~b}$ & $0.78 \pm 0.31 \mathrm{a}$ \\
Grease & $0.85 \pm 0.08 \mathrm{a}$ & $0.80 \pm 0.36 \mathrm{~b}$ & $0.86 \pm 0.01 \mathrm{a}$ \\
\hline
\end{tabular}

\section{Discussion}

Snail meat is reported to be a high quality food that is rich in protein, low in fat, and a source of many vital minerals required for normal tissue development and maintenance [26,27,28,29,30,31,32]. The results of the present study support these reports. The present study also support the findings that the protein content of snail is comparable with the protein content of donkey meat [26], and higher than the protein content of beef [33]. Biochemical and nutritional composition analysis of snail (Limicolaria flammea) meat provides a profile of components whose contents varied. However, high protein and minerals (calcium, phosphorus) content are indicative of beneficial use in food and feed [34].

Zootechnical parameters are indicators of nutritional efficiency of food [35]. It's generally acknowledged that rats fed the RPP diet experienced a loss of mass. This loss of mass would be due to a very large protein deficit in diet, which would result in an indeterminate value of net ingested protein (PNU). According to [36], 9 to 18\% of net protein ingested would promote weight gain in rats. Young rats fed the snail diet Limicolaria flammea (ESC) and the control diet (RTC) show an increase in rat weights.

This increase in the weight of young rats fed the snail diet (ESC) is believed to be due to the protein richness (46.65\%) of Limicolaria flammea. Indeed, according to [20], snail meat is an important source of protein and minerals beneficial for a balanced diet. In addition, proteins ensure maintenance of growth or increase in muscle mass and the synthesis of several metabolites that play an essential role in the functioning body. Mineral contents justify the use of snail powder for fortification of foods for infant nutrition [17].

Rat growth could therefore indicate a regular development of rat cellular metabolism. [37,25] reported that food induced growth of $25 \mathrm{~g} / \mathrm{month}$ (or $0.89 \mathrm{~g} / \mathrm{d}$ ) is considered as a good protein source. As a result, snail powder would be an excellent source of protein in the care of malnourished children. Snail powder (Limicolaria flammea), which has caused weight gain in young rats as much as the control diet, could be recommended in the diet of growing children who need protein-rich food.

Similarity in performance (positive variation and weight gain) in rats fed the control diet (RTC) and snail diet (Limicolaria flammea) respectively is believed to be due to an identical effect of proteins in both diets. Indeed, according to [38], ingestion of protein sources with approximately the same protein composition normally leads to almost similar performance when experimental conditions remain unchanged. Organ biometrics is a technique for assessing food quality [39]. Indeed, this measure makes it possible to detect anomalies on organs involved in nutritional metabolism [25]. Kidneys are extremely important and effective organs for body functioning, but they are also extremely sensitive to various substances that can cause abnormalities [20]. Weight of organs in particular (the heart and kidneys), young rats fed the control diet (herring fish (RTC) and young rats fed the snail diet (ESC) don't show any significant difference $(p<0.05)$. This observation would suggest that protein contribution of these diets in the diet of growing rats would contribute to the maintenance of organs weight according to continuous hematopoiesis process. 
A protein defect during this phase would therefore disrupt this process and significantly influence the relative weight organs [40]. Also, according to [20] an interval of 0.77 to $0.90 \mathrm{~g}$ relative kidney weight would indicate a good state of functioning of these organs. To this end, the relative weight of the kidneys $(0.80 \pm 0.04 \mathrm{~g}$ and $0.78 \pm 0.31 \mathrm{~g})$ of rats fed snail feed (ESC) and herring fish feed (RTC) also illustrates the good functioning of these organs and the safety of the snail feed (Limicolaria flammea) in the diet of young rats. This observation would therefore imply that a low kidney mass would indicate a malfunction of this organ due to a dietary restriction [41]. The liver, an organ involved in nutrient metabolism, performs three vital functions, namely purification (cholesterol elimination, transformation of ammonia into urea, etc.), synthesis (synthesis of coagulation factors and cholesterol synthesis, etc.) and storage [20]. However, liver hypertrophy is an indicator of treatment-related abnormality [25,36]. Liver mass $(3.19 \pm 0.96 \mathrm{~g})$ of rats fed snail feed (Limicolaria flammea) and rats fed herring fish $(3.01 \pm 0.32 \mathrm{~g})$ (Clupea harengus) don't differ significantly ( $<<0.05)$. These values are in line with those reported by [20] on feeding young people with dokounou (3.13-3.70g). Thus, consumption of snails (Limicolaria flammea) would not affect functioning of rat liver. However, a low liver mass observed in RPP diet $(2.17 \pm 0.41 \mathrm{~g})$ is believed to be caused by a low level of ingestion of this diet [41].

Nutritional efficacy of a food in wistar rat is assessed by determining the food (CEA) and protein (CEP) efficiency coefficients. Apart from rats fed the RPP diet, protein efficiency coefficients of rats fed the PCR diet and the ESC diet are $2.81 \pm 0.31$ and $2.7 \pm 0.29$ respectively and show no significant difference $(\mathrm{p}<0.05)$. These values are even beyond the range defined by [42] who gives a qualitative mention to any protein with CEP greater than 2, thus revealing advantage of using Limicolaria flammea powder in human food.

The digestibility content $(84.12 \pm 1.31 \%$ and $88.14 \pm 0.9 \%)$ of the diets (RTC and ESC) respectively showed that proteins contained in these diets are equally assimilated by rats. Indeed, according to [43], apparent digestibility (AD) more than $70 \%$ is desired in food. These results are in line with those highlighted by [44]. Similarly, the high value of relative digestibility (RD) indicates the importance that the snail Limicolaria flammea would represent in the supplementation of low-protein diets. Also, according to [36] actual digestibility greater than apparent digestibility is an indicator that supports nutritional improvement of food.

Biological value (BV) of a food's protein reflects its bioavailability in body (Bouafou et al., 2011). Biological value of ESC diet is $93.66 \pm 0.42 \%$. Thus, $93.66 \%$ of proteins contained in this diet would normally be assimilated by the body. This content is similar to that reported by [44].

\section{Conclusion}

This study was conducted to test impact of eating snail meat (Limicolaria flammea) on the growth of wistar rats. The study (in vivo) on wistar rats showed that the diet (ESC) based on snail flesh improved the zootechnical parameters of rats by its richness in nutrients (proteins, ash, minerals). In view of the results obtained, Limicolaria flammea snail meat could be used in animal feed, food industry (infant flours, etc.). Snail production and consumption would go a long way in enhancing nutritional balance of diet.

\section{Compliance with ethical standards}

\section{Acknowledgments}

This work was supported by a PhD grant to the first author. The authors are grateful to the Laboratory of Biocatalysis and Bioprocessing (Nangui Abrogoua University, Abidjan Côte d'Ivoire) and Higher Normal School (ENS) of Felix Houphouët-Boigny University (Abidjan, Côte d'Ivoire) for technical assistances.

\section{Disclosure of conflict of interest}

Authors have declared that no competing interests exist.

\section{References}

[1] Ajayi SS, Tewe 00, Mariarty C and Awesu MO. (1978). Observatinos on the biological and nutritive value of the African giant snail (Archachatina marginata). East African Wildlife Journal, 16, 85-95.

[2] Adeyeye EI. (1996). Waste Yield, Proximate and Mineral Composition of three different types of land snails found in Nigeria. International Journal of Food Science and Nutrition, 47 (2), 111-116. 
[3] Akintomide IA. (2004). Tropical snail farming. Oak Ventures Publishers, Lagos, Nigeria, 5-6.

[4] Beckett WH. (1964). Akokoaso -A Survey of a Gold Coast Village: Monograph of snails Anthropology, 10 London School of Economics, 9-14.

[5] Cobbinah JR. (1993). Snail farming in West Africa; A Practical Guide, Technical Centre for Agricultural and Rural Co-operation (CTA), Sayee Publishing Company, United Kingdom, 18 - 20.

[6] Ebenebe CI. (2000). Mini-livestock production in Nigeria. The present and the future. Proc., 5th Ann., Conf., ASAN, Port Harcourt, Nigeria, 19-22.

[7] Akinnusi O. (1998). A practical approach to backyard snail farming, Nig. J. Animal Prod, 25(2), 193 - 197.

[8] Awah AA, Lalabe BC, Nasiru I and Omo-Erigbe P. (2009). Comparative Studies on the Composition and Purchase Costs of some edible land snails in Nigeria, Tropicultura, 27(1), 54-57.

[9] Raut SK and Barker MG. (2002). Achatina fulica Bowdich and other Achatinidae as pests in tropical agriculture. In: Barker, G. M. (ed.), Molluscs as Crop Pests. CABI Publishing, Wallingford, 55-114.

[10] Tan SK and Clements RG. (2011). Limicolaria flammea (Müller, 1774), another potentially invasive African land snail in tropical Asia. Trop. Conserv. Sci, 4(1), 97-102.

[11] Cirlan AF and Sindilar E. (2009). Observations regarding the physical and chemical composition of the meat from the Helix pomatia snail. Journal Lucrari stiintifice-Medicina Veterinara, 52(11), 860-862.

[12] Okonkwo TM and Anyaene LU. (2009). Meat yield and the effects of curing on the characteristics of snail meat. Journal of Tropical Agriculture, Food, Environment and Extension, 8, 66-73.

[13] Ligaszewski M, Lysak A and SurÓwka K. (2005). Chemical composition of the meat of Helix pomatia L. snails from the natural population and the derived breeding population. Roczniki Naukowe Zootechniki, 32, 33-45.

[14] FAO. (2015). La situation des marchés des produits agricoles 2015-16. Commerce et sécurité alimentaire: trouver un meilleur équilibre entre les priorités nationales et le bien commun Rome.

[15] FAO. (2017a). The future of food and agriculture-trends and challenges. Rome.

[16] Okon B, Ibom LA, Ina-Ibor OB and Owai PU. (2016). Nutritional evaluation of giant african land snail Archachatina marginata var. saturalis) fed diet containing full fat rubber as a replacement for soybean. Nigerian Journal of Agriculture, Food and Environment, 12 (2), 1-8.

[17] Daina I, Ale Ksandrs J, Vita S and Vita S. (2014). Evaluation of nutrion value of roman snail's (Helix pomata) meat obtained in Latvia .FOODBALT.

[18] Sodjinou E, Biaou G and Codjia J-C. (2002). Caractérisation du marché des escargots géants africains (achatines) dans les départements de l'Atlantique et du Littoral au Sud-Bénin. Tropicultura, 20(2), 83-88.

[19] Friday E, Uboh I, Williams ON and Essien C. (2014). Effect of processing on the proximate and Mineral Composition of Archachatina marginata and Achatina achatina. Food and Public Health, 4(1), 10-14.

[20] Kouadio EJP, Konan HK, Brou KS, Dabonné S, Dué AE and Kouamé LP. (2015). Etudes de quelques paramètres de croissance et de valeur nutritive des variétés d'escargot Archachatina marginata (Swainson) élevées en milieu naturel. Tropicultura, 33 (1), 38-45.

[21] AOAC. (1990). Official methods of analysis 15 edition. Washington DC, 222-245.

[22] BIPEA. (1976). Bureau Interprofessionnel d'Etudes Analytiques. Recueil de méthodes d'analyse des communautés européennes, 110.

[23] FAO. (1994). 4. Pulses and derived products, In Definition and classification of commodities. Rome: FAO.

[24] James CS. (1995). Analytical Chemistry of Foods, Blackie Academic and Professional, Glasgow, U.K, 64 - 65.

[25] Adrian J, Rabache M and Fragne R. (1991). Techniques d'analyse nutritionnelle. In Principes de techniques d'analyse. Ed: Lavoisier TEC \& DOC. Paris, 451-478.

[26] Ademolu KO, Idowu AB, Mafiana CF and Osinowo OA. (2004). Performance, proximate and mineral analyses of African giant land snail (Archachatina marginata) fed different nitrogen sources. Afr J Biotech, 3(8), 412-417.

[27] Özogul Y, Özogul F and Olgunoglu IA. (2005). Fatty acid profile and mineral content of the wild snail (Helix pomatia) from the region of the South of the Turkey, European Food Research and Technology, 221, 547-549. 
[28] Milinsk MC, Padre R, Hayashi C, De Oliveira CC, Visentainer JV, de Souza NE and Matsushita M. (2006). Effect of feed protein and lipid contents on fatty acid pro-file of snail (Helix aspersa maxima) meat. Journal of Food Composition and Analysis, 19, 212-216.

[29] Fagbuaro O, Oso JA, Edward JB and Ogunleye RF. (2006). Nutritional status of four species of giant land snails in Nigeria. J Zhejiang Univ. Sci. B, 7(9), 686-689.

[30] Funmilayo SM. (2008). Preliminary investigation of the growth performance of Giant Land Snail (Archachatina marginata) fed with selected household wastes. African Journal of Agricultural Research, 3(9), 647-649.

[31] Uboh FE, Ebong PE and Mbi E. (2010). Cultural discrimination in the Consumption of black snail (Archatina marginata) and white snail (Achatina achatina); any scientific justification? International Research Journal of Microbiology, 1(1), 013-017.

[32] Çagiltay F, Erkan N, Tosun D and Selçuk A. (2011). Amino acid, fatty acid, vitamin and mineral contents of the edible garden snail (Helix aspersa). Journal of FisheriesSciences.com, 5(4), 354-363.

[33] Aganga AA, Aganga AO, Thema T and Obocheleng KO. (2003). Carcass analysis and meat composition of the Donkey. Pakistan J. Nutri, 2 (3), 138-147.

[34] Envin BJA, Ekissi ESG, Sea TB and Kouame LP. (2018). Biochemical and nutritional composition of garden snail (Limicolaria flammea) flesh consumed in Côte d'Ivoire. Journal of Basic and Applied Research, 4(4), 63-70.

[35] [35] Silva HJ, Marinho SMO, Silva AETM, Albuquerque CG, Moraes SRA and Manhães De Castro R. (2005). Protocol of meensuration to avaliation of indicators of somatic development of Wistar rats. International Journal of Morphology, 23(3), 227-230.

[36] Bouafou K, Konan BA, Meite A, Kouame G and Kati-Coulibally S. (2011). Substitution de la farine de poisson par la farine d'asticots séchés dans le régime du rat en croissance: risques pathologiques? .Journal of Applied Biosciences, 48, 3279-3283.

[37] Dally T, Meite A, Kouame KG, Bouafou KGM and Kati-Coulibali S. (2010). Efficacité nutritionnelle de trois mets Ivoiriens: cabatoh à la sauce dah au nord; foutou igname à la sauce gouagouassou au centre; riz cuit à la sauce graine à l'ouest. Journal of Applied Biosciences, 33, 2084-2090.

[38] Kouadio NJ, Koua A-YG, Cissé M, Kra KAS and Niamké LS. (2016). Nutritional status of baked dockounou formulated with senescent plantain and six sell flours. International Journal of food and nutritional sciences, 4(5), 17-26.

[39] Meite A, Dally T, Ouattara H, Bouafou MGK, Kouame GK and Kati-Coulibaly S. (2017). Blood Biochemical Parameters and Biometry of organs In Rats Fed With breads Fortified With the Flour of Non-Delipidated Seeds of Citrullus lanatus (Cucurbitaceae). International Journal of Innovation and Applied Studies, 20(2), 561-567.

[40] Calder CC, Costa-Rosa LFBP and Curi, R. (1995). Effects of feedings lipids of different fatty acid compositions upon rat lymphocyte proliferation- Life Sci, 56(6), 455-463.

[41] Moriyama M, Durham AD and Moriyama H. (2008). Multiple roles of Notch signaling in the regulation of epidermal development. Dev Cell, 14, 594-604.

[42] Friedman M. (1996). Nutritional Value of Proteins from Different Food Sources: A Review. J. Agric. Food Chem, 44, 6-29.

[43] FAO/WHO. (1991). Protein quality evaluation. (Report of Joint FAO/WHO Expert Consultation, FAO Food and Nutrition Paper 51). FAO/WHO, Rome, Italy, 466.

[44] Rougbo NP, Kouadio NJ, Sea TB and Kouamé LP. (2018). Nutritional assessment of precooked flour formulated from corn (Zea mays), soybean (Glycine max) and groundnut (Arachis hypogaea) flours consumed in Côte d'Ivoire. European Journal of Food Science and Technology, 6(4), 1-10.

\section{How to cite this article}

Envin BJA, Ekissi ESG, Sea TB, Rougbo NP and Kouamé LP. (2020). Effects (in vivo) of the nutritional potential of snail Limicolaria flammea (Müller) meat on wistar rats. GSC Biological and Pharmaceutical Sciences, 11(2), 71-79. 